\title{
Knowledge, Practice and Attitudes of Preventive Measures against Coronavirus Infection among Pregnant Women in Egypt
}

Hanan Morsy Salim Metwally", Mervat Mostafa Abd El Monem Desoky

Lecturer of Obstetrics and Gynecological Nursing, Faculty of Nursing, Zagazig University, Egypt

\author{
DOI: $10.36348 /$ sjnhc.2020.v03i06.001 \\ | Received: 21.05.2020 | Accepted: 31.05 .2020 | Published: 06.06.2020 \\ *Corresponding author: Hanan Morsy Salim Metwally
}

Abstract

Background: Unprecedented measures have been adopted to control the rapid spread of the ongoing coronavirus disease (COVID-19) epidemic in Egypt. Pregnant women adherence to control measures is affected by their knowledge, attitudes, and practices (KAP) towards COVID-19. Aim: Aim of the study was to assess the knowledge, practice and attitudes of preventive measures against COVID-19 infection among pregnant women. Subjects\& methods: Research design: Across sectional design was used. Setting: The study was carried out in two Maternal and Child Health Centers (Alnahal Medical Centre and Sheba MCH) that are affiliated to the Ministry of Health and Population in Zagazig City, Sharkia Governorate, Egypt, between the period from January 2020 to April 2020. Subjects: All eligible pregnant women who attended for antenatal care during the study period by using simple random sampling. Tools of data collection: A structured interviewing questionnaire that consists of five parts, part one, socio-demographic and obstetric data, part two sources of information on preventive measure against COVID-19 infection, part three, knowledge towards COVID-19 infection and its prevention measures, part four practice of preventive measures of COVID-19 infection and part five attitudes towards COVID-19 infection. Results: The findings of this research showed that more than half of women $(57.6 \%)$ had satisfactory level of total knowledge about the preventive measure of COVID-19 infection. However, the majority of women $(87.6 \%)$ had unsatisfactory level of total practice of preventive measures of COVID-19. Educational level and multiparty were factors significantly associated with poor practice of the preventive measures against coronavirus -19 infection among pregnant women. Conclusion: The study showed that most of the participants had adequate knowledge of preventive measures against COVID-19 infection but the practice of these preventive measures were poor among the participants. Recommendations: Provide continuous health educational program on practice of using preventive measures against COVID-19 infection especially among pregnant women.

Keywords: Knowledge, practice, preventive measures, COVID-19, pregnant women.

Copyright @ 2020: This is an open-access article distributed under the terms of the Creative Commons Attribution license which permits unrestricted use, distribution, and reproduction in any medium for non-commercial use (NonCommercial, or CC-BY-NC) provided the original author and source are credited.

\section{INTRODUCTION}

Coronavirus disease 2019 (COVID-19) is an emerging respiratory disease caused by a novel coronavirus and first identified in Wuhan, China in December 2019. The disease is infectious, with fever, dry cough, weakness, myalgia and dyspnea as its main clinical symptoms. In China, $18.5 \%$ of COVID-19 patients progress to a serious level, characterized by acute respiratory distress syndrome, septic shock, metabolic acidosis that is difficult to cope with and bleeding and coagulation dysfunction $[1,2]$.

Coronaviruses are single-stranded, nonsectioned, enveloped viruses that cause disease ranging from common cold to severe and fatal disease. The term corona virus derives from the Latin word corona, meaning crown or halo; the designation arises from the appearance of coronavirus versions seen by electron microscopy, in which the virus particles show a crownlike fringe usually referred to as spikes [3].

The primary epidemiological risk factors for coronavirus disease 2019 currently include travel from mainland China (especially the province of Hubei) or close contact with infected persons within 14 days of the onset of symptoms. The data indicate a time of incubation of $>5$ days (range, 2-14 days). The average age of hospitalized patients was 49-56 years, with an underlying condition a third to half. Children are rarely recorded. Among hospitalized cases men were more frequent (54-73 percent). In 2 studies documenting 18 coronavirus disease pregnancies in 2019, all were infected in the third trimester and clinical results close to those in non-pregnant adults. In certain cases, fetal distress and preterm delivery were reported. All that 
and two births were cesarean deliveries, and there was no evidence of in utero transmission [3].

The infection has spread to over 110 countries including Egypt prompting World health organization (WHO) to declare it a pandemic on March 11, 2020 [4]. Globally, there were $1,914,916$ confirmed cases of COVID-19 as of 15 April 2020, including 123,010 deaths identified by the WHO. The Egyptian ministry of health reported on 27 February 2020 the first confirmed case of coronavirus disease in Egypt and since then many confirmed cases have been registered across the country in many states [5].

Early efforts have focused on explaining Covid-19's clinical characteristics and outcomes in the general population [6]. However, the disease seems to have a particular effect in specific populations that include those over 65 years of age [7].

As demonstrated by the latest pandemic caused by the 2009 pandemic H1N1 influenza virus and the extreme fetal effects of the Zika virus, emerging infections have had adverse effects on pregnant women and their fetuses [3].

Pregnant women are considered a special category of population due to the unusual immune suppression induced by pregnancy [8]. The immunological and physiological changes in pregnancy might make pregnant women at higher risk of serious disease or death with Covid-19 compared to the general public [7]. However, little information is available about Covid-19 infection during pregnancy [9]. There are limited case series reporting the impact on women affected by coronaviruses during pregnancy [10]. In women infected by other coronavirus infections such as Middle East Respiratory Syndrome (MERS-CoV) and severe acute respiratory syndrome (SARS-CoV), the risk of death in women infected during pregnancy tended to be higher than in non-pregnant women [11].

To reduce the continued spread of the coronavirus disease and its related mortality, the World Health Organization has recommended a range of preventive steps, including daily hand washing with water and soap, social distance, hand and mouth covering when coughing and avoiding eyes, nose and mouth touching [12].

In Egypt, these preventive measures have been adopted to prevent further spread of the virus in the country. The government of Egypt has also engaged in media campaigns to disseminate information on these preventive measures to the general public because Egypt is one of the biggest countries in the Arab region, Africa and the Middle East. With more than 100 million citizens, Egypt is among the most populous countries in Africa. This high number of citizens could be associated with a great risk of spread and mortality, especially among old persons and those with chronic diseases [13].

\section{Significance of the Study}

Coronavirus disease pandemic has resulted in death of thousands of people across several countries. Several preventive measures have been recommended to halt the spread of the disease and its associated mortality. However, the level knowledge and practice of these preventive measures against COVID-19 infection among pregnant women, which constitute vulnerable groups, are yet to be evaluated .Therefore, this study aimed to assess the knowledge and practice of the preventive measures of coronavirus infection among pregnant women attending antenatal care at maternal and child health centers.

\section{Definition}

SARS-CoV-2: severe acute respiratory syndrome coronavirus 2 virus (current name of the novel coronavirus, according to the International Committee on Taxonomy of Vi-ruses), virus that causes COVID-19.

\section{Aim of the current study}

The aim of the present study was to assess the knowledge, practice and attitudes of preventive measures against COVID-19 infection among pregnant women

\section{SUBJECTS AND METHODS}

Design of the Study: Across-sectional design was used in the present study

\section{Study Setting}

The study was performed at two Maternal and Child Health Centers (Alnahal Medical Center and Sheba MCH) affiliated with the Zagazig City Ministry of Health and Population, Sharkia Governorate, Egypt.

The reasons given for choosing the above setting, as they are the main health centers in Zagazig where women attend for antenatal follow-up, immunization during pregnancy and other reproductive health services. These also represent a wide variety of individuals with various socio-demographic and obstetric features, as well as attendance levels was high.

\section{Sample Type}

Sampling technique: Research participants were selected using simple random sampling method. All consenting eligible pregnant women who attended during the study period to receive antenatal care.

\section{Sample Size}

Comprehensive sampling of 370 pregnant women were recruited randomly during the study period (4 months) from the above mentioned setting. 


\section{Inclusion Criteria}

The research included all the pregnant women who gave informed consent to participate in the research.

\section{Exclusion Criteria}

Participants who had a problem with verbal contact and full hearing loss were excluded.

\section{Tools of data collection}

The researcher developed a structured Arabiclanguage interview questionnaire on the knowledge, practice and attitudes of preventive measures against coronavirus infection. Following a review of literature on the WHO guidelines on steps to prevent human-tohuman transmission of COVID-19 infection, the questionnaire was developed and audited by highly qualified staff. It was designed using clear language constructs, keeping in mind the educational level of every woman.

Tool one: A structured interviewing questionnaire: it composed of five aspects:

1. Socio-demographic characteristics of the pregnant women included age, level of education, place of residence, job and marital status and obstetrics data, as parity.

2. Sources of information on preventive measure against COVID-19 infection

3. Knowledge towards COVID-19 infection and its prevention measures

4. Practice of preventive measures of COVID-19 infection.

5. Attitudes of participants toward COVID-19 infection

Scoring System: The scoring system of women's knowledge and practice of preventive measures was either 1 (for correct answer) or 0 (for incorrect answer).

Cut off value knowledge and practice

Awareness: A participants were classified as being aware of coronavirus disease pandemic if a positive response (Yes) is obtained to the question 'have you ever heard of coronavirus disease pandemic?'

Satisfactory knowledge: Participants who (score 5-6) on knowledge of coronavirus disease preventive measures questionnaire.

Unsatisfactory knowledge: Women who scored (0-4) on knowledge of coronavirus disease preventive measures questionnaire.

Good practice: Women who scored (score 5-6) on the practice of coronavirus disease preventive measures questionnaire.
Poor practice: Women who scored (0-4) on the practice of coronavirus disease preventive measures questionnaire

\section{Validity}

It was established for face and content validity by a panel of five expertises in obstetrics and gynecological nursing, revising the tools for clarity, relevance, applicability, comprehensiveness, comprehension and ease of implementation and adding minor modifications according to their opinion.

\section{Reliability}

The reliability of the questionnaire was checked by conducting a pretest among pregnant women in the antenatal clinic, by taking $5 \%$ of the sample size. From the pretest, understandability, clarity, and organization of the questionnaire were checked. From the reliability test of knowledge and practice questions, 0.898 Cronbach's alpha value was found.

\section{Ethical Considerations}

An official permission was given by submission of an official letter from the Faculty of Nursing to the study setting's responsible authorities for obtaining their permission for data collection.

All ethical issues were taken into consideration during all phases of the study; the research maintained an anonymity and confidentiality of the subjects.

\section{A pilot study}

A pilot study was performed on a 10 per cent sample of cases. It was done to test the study tools in terms of clarity and feasibility, as the needed time to fill in the tools of the study and detect problems that might interfere with the data collection process. No modification was required, based on the results of the pilot study. Women had been included in the pilot study

\section{Field of the work}

An official permission was given to the directors of maternal and child health care center from the Dean of the Faculty of Nursing, Zagazig University to have approval for conduct of the study after clearing the purpose of the study. The researchers visit the study settings two days/week from 9.00 am to $1 \mathrm{pm}$ for Alnahal center and one day per / week for Sheba unit. The researcher introduced herself to the women and briefly explained the nature and purpose of the study to each woman before the participation and women were enrolled voluntarily after the oral informed consent process. Women were also told that the data collected during the analysis would be confidential and would only be used for research purposes. The researcher interviewed each woman separately in the waiting area before or after examination by an obstetrician. For each woman, it took 25-30 minutes to complete the questionnaires. The participant complete the questionnaire about covid-19 infection, then the 
researcher provide information about covid-19 to each women and how to use the preventive measures correctly. Also the researchers keep in mind protective measures during collecting the data. Finally the researchers provide a guide book in the form of brochures about covid-19 preventive measures.

\section{Statistical Analysis}

All data were collected, tabulated and statistically analyzed using SPSS 20.0 for windows (SPSS Inc., Chicago, IL, USA). Quantitative data were expressed as the mean \pm SD \& median (range), and qualitative data were expressed as number \& percentage. Percent of categorical variables were compared using Chi-square test or Fisher's exact test when appropriate. Spearman's rank correlation coefficient was calculated to assess relationship between various study variables, $(+)$ sign indicate direct correlation \& (-) sign indicate inverse correlation, also values near to 1 indicate strong correlation \& values near 0 indicate weak correlation. All tests were two sided; p-value $<0.05$ was considered statistically significant $(\mathrm{S})$, and $\mathrm{p}$-value $\geq 0.05$ was considered statistically insignificant (NS).

The OR represents the odds that an outcome will occur given a particular exposure, compared to the odds of the outcome occurring in the absence of that exposure. Results are interpreted: An OR of 1.00 means that the two groups were equally likely. An OR higher than 1 means that the first group was more likely to experience the event than the second group. An OR of less than 1 means that the first group was less likely to experience the event
RESULTS

Table-1: Distribution of studied women according to their socio-demographic characteristics and parity $(\mathbf{n}=370)$

\begin{tabular}{|c|c|c|}
\hline \multicolumn{3}{|c|}{$(n=370)$} \\
\hline \multicolumn{3}{|l|}{ Age } \\
\hline$<30$ years & 216 & 58.4 \\
\hline$\geq 30$ years & 154 & 41.6 \\
\hline Mean \pm SD range & \multicolumn{2}{|c|}{$28.2 \pm 4.8(18-42)$} \\
\hline \multicolumn{3}{|l|}{ Residence } \\
\hline Rural & 251 & 67.8 \\
\hline Urban & 119 & 32.2 \\
\hline \multicolumn{3}{|l|}{ Education level } \\
\hline Illiterate & 22 & 5.9 \\
\hline Primary school & 65 & 17.6 \\
\hline Secondary & 234 & 63.2 \\
\hline University & 49 & 13.3 \\
\hline \multicolumn{3}{|l|}{ Occupation } \\
\hline Housewife & 285 & 77.0 \\
\hline Employed & 85 & 23.0 \\
\hline \multicolumn{3}{|l|}{ Marital status } \\
\hline Married & 285 & 77.0 \\
\hline Separated & 52 & 14.1 \\
\hline widowed & 33 & 8.9 \\
\hline \multicolumn{3}{|l|}{ Income level } \\
\hline indebt & 64 & 17.3 \\
\hline Just meet life expenses & 196 & 53.0 \\
\hline insufficient & 110 & 29.7 \\
\hline \multicolumn{3}{|l|}{ Parity } \\
\hline 0 & 43 & 11.6 \\
\hline 1 & 37 & 10.0 \\
\hline 2 & 123 & 33.2 \\
\hline 3 & 144 & 38.9 \\
\hline 4 & 23 & 6.3 \\
\hline
\end{tabular}

Table-1 shows that, the mean age of the studied women was $28.2 \pm 4.8$ years. More than three fourth of them $(77.0 \%)$ were married and housewives. Regarding level of education, they had secondary level of education (63.2\%), were living in rural areas $(67.8 \%)$. Most of them were multiparous (78.4\%).

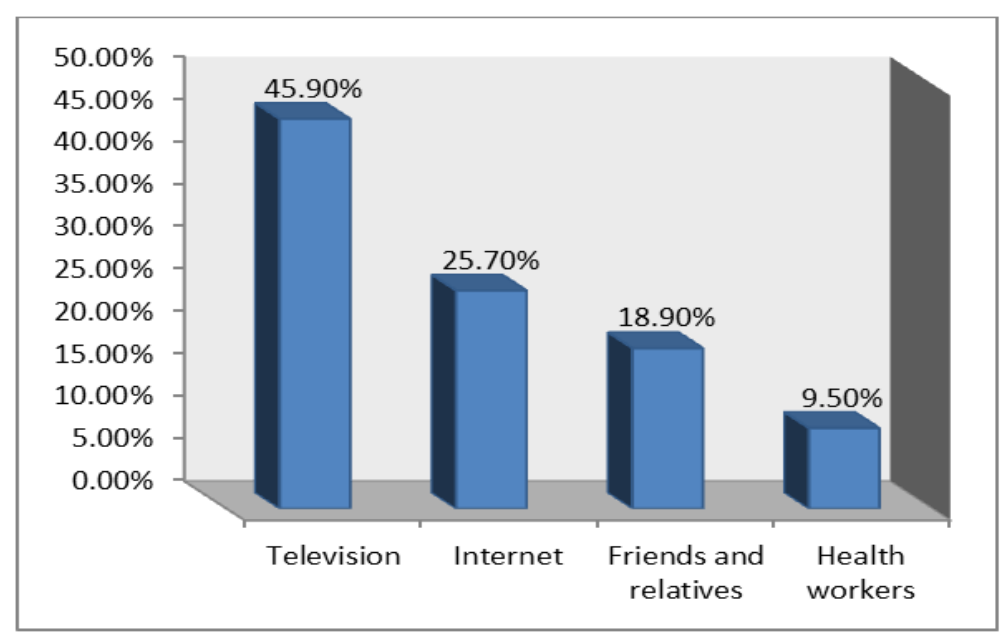

Fig-1: Sources of information on preventive measure against COVID-19 infection 
Figure-1 illustrates that, the most common source of women's information on preventive measure against COVID-19 infection was television (45.90\%) followed by internet, friends and relatives and health workers $(25.70 \%, 18.90 \% \& 9.50 \%$ respectively).

Table-2: Distribution of studied women according to their knowledge towards COVID-19 infection measures $(\mathbf{n}=370)$

\begin{tabular}{|c|c|c|c|c|}
\hline \multirow[t]{3}{*}{ Knowledge items } & \multicolumn{4}{|c|}{ Information } \\
\hline & \multicolumn{2}{|l|}{ yes } & \multicolumn{2}{|l|}{ no } \\
\hline & No. & $\%$ & No. & $\%$ \\
\hline Are you aware of ongoing COVID-19 infection pandemic? & 370 & $100.0 \%$ & 0 & 0.0 \\
\hline $\begin{array}{l}\text { The symptoms of COVID-19 infection } \\
\text { Fever }\end{array}$ & 323 & $87.3 \%$ & 47 & $12.7 \%$ \\
\hline Headache & 291 & $78.6 \%$ & 79 & $21.4 \%$ \\
\hline Runny nose & 291 & $78.6 \%$ & 79 & $21.4 \%$ \\
\hline Cough & 315 & $85.1 \%$ & 55 & $14.9 \%$ \\
\hline Difficulty breathing & 263 & $71.1 \%$ & 107 & $28.9 \%$ \\
\hline $\begin{array}{l}\text { Behavior do when you have the above symptoms } \\
\text { Stay at home }\end{array}$ & 232 & $62.7 \%$ & 138 & $37.3 \%$ \\
\hline Wear face mask & 262 & $70.8 \%$ & 108 & $29.2 \%$ \\
\hline Inform your health care provider in advance before visit to hospital & 195 & $52.7 \%$ & 175 & $47.3 \%$ \\
\hline $\begin{array}{l}\text { Knowledge about COVID-19 infection } \\
\text { There currently is no effective cure for COVID-2019, but early symptomatic } \\
\text { and supportive treatment can help most patients recover from the infection }\end{array}$ & 231 & $62.4 \%$ & 139 & $37.6 \%$ \\
\hline All persons with COVID-2019 will develop to severe case & 240 & $64.9 \%$ & 130 & $35.1 \%$ \\
\hline $\begin{array}{l}\text { Eating or contacting with animals would result in the infection by the COVID- } \\
19 \text { virus }\end{array}$ & 265 & $71.6 \%$ & 105 & $28.4 \%$ \\
\hline $\begin{array}{l}\text { Persons with COVID-2019 cannot infect the virus to others when a fever is } \\
\text { not present }\end{array}$ & 254 & $68.6 \%$ & 116 & $31.4 \%$ \\
\hline The COVID-19 virus spreads via respiratory droplets of infected individuals & 330 & $89.2 \%$ & 40 & $10.8 \%$ \\
\hline $\begin{array}{l}\text { It is not necessary for children and young adults to take measures to prevent } \\
\text { the infection by the COVID-19 virus }\end{array}$ & 181 & $48.9 \%$ & 189 & $51.1 \%$ \\
\hline $\begin{array}{l}\text { Isolation and treatment of people who are infected with the COVID-19 virus } \\
\text { are effective ways to reduce the spread of the virus }\end{array}$ & 305 & $82.4 \%$ & 65 & $17.6 \%$ \\
\hline $\begin{array}{l}\text { People who have contact with someone infected with the COVID-19 virus } \\
\text { should be immediately isolated in a proper place. In general, the observation } \\
\text { period is } 14 \text { days. }\end{array}$ & 269 & $72.7 \%$ & 101 & $27.3 \%$ \\
\hline
\end{tabular}

Table-2 demonstrates that, all of the women (100\%) were aware of ongoing COVID-19 infection. Most of them reported fever and cough to be symptoms of COVID-19 infection ( $87.3 \% \& 85.1 \%$ respectively). More than two thirds of women $(70.8 \%)$ reported to wear face mask when they had that symptoms, (62.7\%) of them reported to stay at home and $(52.7 \%)$ reported to inform their health care provider before going to hospital. The majority of women $(89.2 \%)$ reported that the COVID-19 virus spreads via respiratory droplets of infected individuals.

Table-3: Distribution of studied women according to their knowledge towards prevention measures of COVID-19 infection $(\mathbf{n}=370)$

\begin{tabular}{|c|c|c|c|c|}
\hline \multirow[t]{3}{*}{ Knowledge about the preventive measure of COVID-19 infection } & \multicolumn{4}{|c|}{ Information } \\
\hline & \multicolumn{2}{|l|}{ yes } & \multicolumn{2}{|l|}{ no } \\
\hline & No. & $\%$ & No. & $\%$ \\
\hline $\begin{array}{l}\text { Knowledge about the preventive measure of COVID-19 infection } \\
\text { Washing hands frequently with soap and water or rubbing hands with } \\
\text { alcohol-based sanitizers }\end{array}$ & 289 & $78.1 \%$ & 81 & $21.9 \%$ \\
\hline Maintaining at least 1 meter distance between yourself and others & 226 & $61.1 \%$ & 144 & $38.9 \%$ \\
\hline Avoid touching eyes, nose and mouth with hands & 301 & $81.4 \%$ & 69 & $18.6 \%$ \\
\hline Covering mouth and nose when coughing or sneezing & 315 & $85.1 \%$ & 55 & $14.9 \%$ \\
\hline Wear face mask & 262 & $70.8 \%$ & 108 & $29.2 \%$ \\
\hline Stay at home & 232 & $62.7 \%$ & 138 & $37.3 \%$ \\
\hline $\begin{array}{l}\text { Knowledge about the preventive measure of COVID-19 infection } \\
\text { Satisfactory level }\end{array}$ & 213 & 57.6 & 157 & 42.4 \\
\hline
\end{tabular}


Table-3 reveals that, more than half of women $(57.6 \%)$ had satisfactory level of total knowledge about the preventive measure of COVID-19 infection. women knew that preventive measure of COVID-19 infection were covering mouth and nose when coughing or sneezing, avoid touching eyes, nose and mouth with hands, washing hands frequently with soap and water or rubbing hands with alcohol-based sanitizers, wear face mask, stay at home and maintaining at least 1 meter distance between themselves and others $(85.1 \%, 81.4 \%$, $78.1 \%, 70.8 \%, 62.7 \%$ \& $61.1 \%$ respectively).

Table-4: Distribution of studied women according to their practice of preventive measures of COVID-19 infection $(\mathbf{n}=370)$

\begin{tabular}{|c|c|c|c|c|}
\hline \multirow[t]{3}{*}{ Practice of preventive measures of COVID-19 infection items } & \multicolumn{4}{|c|}{ Practice } \\
\hline & \multicolumn{2}{|l|}{ yes } & \multicolumn{2}{|l|}{ no } \\
\hline & No. & $\%$ & No. & $\%$ \\
\hline $\begin{array}{l}\text { practice of preventive measures of COVID-19 infection } \\
\text { Washing hands frequently with soap and water or alcohol-based sanitizers }\end{array}$ & 163 & $44.1 \%$ & 207 & $55.9 \%$ \\
\hline Maintaining at least 1 meter distance between yourself and others & 168 & $45.4 \%$ & 202 & $54.6 \%$ \\
\hline Avoid touching eyes, nose and mouth with hands & 160 & $43.2 \%$ & 210 & $56.8 \%$ \\
\hline Wear face mask & 166 & $44.9 \%$ & 204 & $55.1 \%$ \\
\hline Stay at home & 153 & $41.4 \%$ & 217 & $58.6 \%$ \\
\hline In recent days, have you avoid gone to any crowded place? & 92 & $24.9 \%$ & 278 & $75.1 \%$ \\
\hline Total Women practice of preventive measures of COVID-19 infection Satisfactory & 46 & $12.4 \%$ & 324 & $87.6 \%$ \\
\hline
\end{tabular}

Table-4 shows that, the majority of women $(87.6 \%)$ had unsatisfactory level of total practice of preventive measures of COVID-19 infection. Only $(12.4 \%)$ of women had satisfactory level of total practice. As women's responses regarding practice of preventive measures against COVID-19 infection was maintaining at least 1 meter distance between yourself and others $(45.4 \%)$, wear face mask $(44.9 \%)$, frequent hand washing with soap and water $(44.1 \%)$, stay at home $(41.4 \%)$ and avoid going to any crowded place $(24.9 \%)$.

Table-5: Distribution of studied women according to their attitudes toward COVID-19 infection $(n=370)$

\begin{tabular}{|c|c|c|c|c|}
\hline \multirow[t]{3}{*}{ Attitudes toward COVID-19 infection } & \multicolumn{4}{|c|}{ Information } \\
\hline & \multicolumn{2}{|l|}{ yes } & \multicolumn{2}{|l|}{ no } \\
\hline & No. & $\%$ & No. & $\%$ \\
\hline $\begin{array}{l}\text { Attitudes toward COVID-19 infection } \\
\text { A1.Do you agree that COVID-19 will finally be successfully controlled? }\end{array}$ & 257 & $69.5 \%$ & 113 & $30.5 \%$ \\
\hline A2. Do you have confidence that Egypt can win the battle against the COVID-19 virus? & 321 & $86.8 \%$ & 49 & $13.2 \%$ \\
\hline
\end{tabular}

Table-5 reveals that, the majority of women (86.8\%) had confidence that Egypt can win the battle against the COVID-19 virus. More than two thirds of them $(69.5 \%)$ agreed that COVID-19 will finally be successfully controlled.

Table-6: Association between level of knowledge about preventive measures against COVID-19 infection among studied women and their socio-demographic characteristics and parity $(n=370)$

\begin{tabular}{|c|c|c|c|c|c|c|c|c|}
\hline \multirow[t]{3}{*}{$\begin{array}{l}\text { Demographic } \\
\text { items }\end{array}$} & \multicolumn{4}{|c|}{$\begin{array}{l}\text { level of knowledge of preventive measures } \\
\text { against COVID-19 infection }\end{array}$} & \multirow[t]{3}{*}{ No. } & \multirow[t]{3}{*}{$\chi^{2}$} & \multirow[t]{3}{*}{ p-value } & \multirow[t]{3}{*}{ OR(95\% CI) } \\
\hline & \multicolumn{2}{|c|}{ Adequate $\geq 80$} & \multicolumn{2}{|c|}{ Inadequate $<80$} & & & & \\
\hline & no & $\%$ & no & $\%$ & & & & \\
\hline \multicolumn{9}{|l|}{ Age } \\
\hline$<30$ years & 136 & 62.96 & 80 & 37.04 & 216 & 6.2 & 0.013 & $1.7(1.1-2.6)$ \\
\hline$\geq 30$ years & 77 & 50.00 & 77 & 50.00 & 154 & & & 1 \\
\hline \multicolumn{9}{|l|}{ Residence } \\
\hline Rural & 141 & 56.18 & 110 & 43.82 & 251 & 0.62 & 0.43 & $0.84(0.54-1.3)$ \\
\hline Urban & 72 & 60.50 & 47 & 39.50 & 119 & & & 1 \\
\hline \multicolumn{9}{|l|}{ Education level } \\
\hline Illiterate & 10 & 45.45 & 12 & 54.55 & 22 & & & 1 \\
\hline Primary school & 35 & 53.85 & 30 & 46.15 & 65 & 0.016 & 0.89 & $1.1(0.34-3.6)$ \\
\hline Secondary & 119 & 50.85 & 115 & 49.15 & 234 & & & $1.04(0.38-2.9)$ \\
\hline University & 49 & 100.00 & 0 & .00 & 49 & & & N/A \\
\hline \multicolumn{9}{|l|}{ Occupation } \\
\hline Housewife & 166 & 58.25 & 119 & 41.75 & 285 & 0.23 & 0.63 & $1.1(0.69-1.838$ \\
\hline Employed & 47 & 55.29 & 38 & 44.71 & 85 & & & 1 \\
\hline
\end{tabular}




\begin{tabular}{|l|l|l|l|l|l|l|l|l|}
\hline Marital status & &. & &. & & & & \\
\hline Married & 154 & 54.04 & 131 & 45.96 & 285 & $\mathbf{9 . 7}$ & $\mathbf{0 . 0 0 8}$ & 1 \\
\hline Separated & 32 & 61.54 & 20 & 38.46 & 52 & & & $1.4(0.85-3.3)$ \\
\hline widowed & 27 & 81.82 & 6 & 18.18 & 33 & & & $3.8(2-19)$ \\
\hline Income level & &. & &. & & & & \\
\hline indebt meet life & 44 & 68.75 & 20 & 31.25 & 64 & & & $2.6(6.7-101)$ \\
\hline $\begin{array}{l}\text { Just } \\
\text { expenses }\end{array}$ & 119 & 60.71 & 77 & 39.29 & 196 & $\mathbf{1 0 . 6}$ & $\mathbf{0 . 0 0 5}$ & $1.85(0.97-5.4)$ \\
\hline insufficient & 50 & 45.45 & 60 & 54.55 & 110 & & & 1 \\
\hline Parity & &. & &. & & & & \\
\hline 0 & 24 & 55.81 & 19 & 44.19 & 43 & & & 1 \\
\hline 1 & 18 & 48.65 & 19 & 51.35 & 37 & & & $0.75(0.15-1.5)$ \\
\hline 2 & 73 & 59.35 & 50 & 40.65 & 123 & 2.8 & 0.59 & $1.16(.07-0.62)$ \\
\hline 3 & 87 & 60.42 & 57 & 39.58 & 144 & & & $1.2(0.97-6.3)$ \\
\hline 4 & 11 & 47.83 & 12 & 52.17 & 23 & & & $0.73(0.39-5.8)$ \\
\hline
\end{tabular}

Table-6 points out that there were statistically significant relations between the studied women's level of knowledge about preventive measures against COVID-19 infection and their age, marital status, and income level with $\mathrm{p}$-value $<0.05$. Younger women $<30$ years had adequate level of knowledge than older women $(62.96 \%$ \& $50.00 \%$ respectively). Moreover, women whose income level was indept and just meet life expenses had adequate level of knowledge than those who had insufficient income $(68.75 \%, 60.71$ $\& 45.45 \%$ respectively).

Table-7: Association between level of practice about preventive measures against COVID-19 infection among studied women and their socio-demographic characteristics and parity $(n=370)$

\begin{tabular}{|c|c|c|c|c|c|c|c|c|}
\hline \multirow[t]{3}{*}{ Demographic items } & \multicolumn{4}{|c|}{$\begin{array}{l}\text { level of practice of preventive measures against COVID-19 } \\
\text { infection }\end{array}$} & \multirow[t]{3}{*}{ No. } & \multirow[t]{3}{*}{$\chi^{2}$} & \multirow[t]{3}{*}{$\mathbf{p}$} & \multirow[t]{3}{*}{ OR(95\%CI $)$} \\
\hline & \multicolumn{2}{|c|}{ Adequate $\geq 80$} & \multicolumn{2}{|c|}{ Inadequate $<80$} & & & & \\
\hline & no & $\%$ & no & $\%$ & & & & \\
\hline \multicolumn{9}{|l|}{ Age } \\
\hline$<30$ years & 26 & 12.04 & 190 & 87.96 & 216 & 0.08 & 0.78 & $\begin{array}{l}0.92(0.49- \\
1.71)\end{array}$ \\
\hline$\geq 30$ years & 20 & 12.99 & 134 & 87.01 & 154 & & & \\
\hline \multicolumn{9}{|l|}{ Residence } \\
\hline Rural & 34 & 13.55 & 217 & 86.45 & 251 & 0.89 & 0.35 & $1.4(0.69-2.81)$ \\
\hline Urban & 12 & 10.08 & 107 & 89.92 & 119 & & & \\
\hline \multicolumn{9}{|l|}{ Education level } \\
\hline Illiterate & 0 & .00 & 22 & 100.00 & 22 & & & N/A \\
\hline Primary school & 6 & 9.23 & 59 & 90.77 & 65 & 12.5 & 0.005 & 1 \\
\hline Secondary & 27 & 11.54 & 207 & 88.46 & 234 & & & $1.28(.52-3.5)$ \\
\hline University & 13 & 26.53 & 36 & 73.47 & 49 & & & $\begin{array}{l}3.55(1.23- \\
10.8)\end{array}$ \\
\hline \multicolumn{9}{|l|}{ occupation } \\
\hline Housewife & 36 & 12.63 & 249 & 87.37 & 285 & 0.045 & 0.83 & $\begin{array}{l}1.08(0.51- \\
2.29)\end{array}$ \\
\hline Employed & 10 & 11.76 & 75 & 88.24 & 85 & & & 1 \\
\hline \multicolumn{9}{|l|}{ Marital status } \\
\hline Married & 37 & 12.98 & 248 & 87.02 & 285 & 1.38 & 0.5 & 1 \\
\hline Separated & 4 & 7.69 & 48 & 92.31 & 52 & & & $0.56(.21-2.4)$ \\
\hline widowed & 5 & 15.15 & 28 & 84.85 & 33 & & & $1.2(.59-7.2)$ \\
\hline \multicolumn{9}{|l|}{ income } \\
\hline indebt & 9 & 14.06 & 55 & 85.94 & 64 & 0.88 & 0.64 & $1.47(.55-3.8)$ \\
\hline $\begin{array}{l}\text { Just meet life } \\
\text { expenses }\end{array}$ & 26 & 13.27 & 170 & 86.73 & 196 & & & $1.38(0.65-3)$ \\
\hline insufficient & 11 & 10.00 & 99 & 90.00 & 110 & & & 1 \\
\hline \multicolumn{9}{|l|}{ parity } \\
\hline 0 & 3 & 6.98 & 40 & 93.02 & 43 & & & 1 \\
\hline 1 & 0 & .00 & 37 & 100.00 & 37 & & & N/A \\
\hline 2 & 14 & 11.38 & 109 & 88.62 & 123 & 21 & 0.005 & $1.7(0.21-3.9)$ \\
\hline 3 & 20 & 13.89 & 124 & 86.11 & 144 & & & $2.15(0.65-9.4)$ \\
\hline 4 & 9 & 39.13 & 14 & 60.87 & 23 & & & $8.5(2-42)$ \\
\hline
\end{tabular}

\section{$\chi 2=$ chi square test of significant}


Table-7 demonstrates that there were statistically significant relations between the studied women's level of practice about preventive measures against COVID-19 infection and their education level and parity with p-value $<0.05$. Women who had university education had higher practice level than other education levels $(26.53 \%$ \& $20.77 \%$ respectively). Regarding parity, multiparous women had higher practice level than primiparous $(64.40 \%$ \& $6.98 \%$ respectively).

Table-8: Association between attitude about COVID-19 infection among studied women and their sociodemographic characteristics and parity $(n=370)$

\begin{tabular}{|c|c|c|c|c|c|c|c|c|}
\hline \multirow[t]{3}{*}{ Demographic items } & \multicolumn{4}{|c|}{ Attitude about COVID-19 infection } & \multirow[t]{3}{*}{ No. } & \multirow[t]{3}{*}{$\chi^{2}$} & \multirow[t]{3}{*}{$\mathbf{p}$} & \multirow[t]{3}{*}{ OR(95\% CI $)$} \\
\hline & \multicolumn{2}{|c|}{ agree } & \multicolumn{2}{|c|}{ disagree } & & & & \\
\hline & no & $\%$ & no & $\%$ & & & & \\
\hline \multicolumn{9}{|l|}{ Age } \\
\hline$<30$ years & 137 & 63.43 & 79 & 36.57 & 216 & 8.9 & 0.003 & $0.49(0.31-0.79)$ \\
\hline$\geq 30$ years & 120 & 77.92 & 34 & 22.08 & 154 & & & 1 \\
\hline \multicolumn{9}{|l|}{ Residence } \\
\hline Rural & 176 & 70.12 & 75 & 29.88 & 251 & 0.16 & 0.69 & $1.1(0.69-1.7)$ \\
\hline Urban & 81 & 68.07 & 38 & 31.93 & 119 & & & 1 \\
\hline \multicolumn{9}{|l|}{ Education level } \\
\hline Illiterate & 19 & 86.36 & 3 & 13.64 & 22 & & & 1 \\
\hline Primary school & 43 & 66.15 & 22 & 33.85 & 65 & 3.4 & 0.33 & $0.31(.07-1.1)$ \\
\hline Secondary & 162 & 69.23 & 72 & 30.77 & 234 & & & $0.36(.08-1.14)$ \\
\hline University & 33 & 67.35 & 16 & 32.65 & 49 & & & $0.33(.07-1.2)$ \\
\hline \multicolumn{9}{|l|}{ occupation } \\
\hline Housewife & 193 & 67.72 & 92 & 32.28 & 285 & 1.8 & 0.18 & $0.69(0.4-1.19)$ \\
\hline Employed & 64 & 75.29 & 21 & 24.71 & 85 & & & 1 \\
\hline \multicolumn{9}{|l|}{ Marital status } \\
\hline Married & 189 & 66.32 & 96 & 33.68 & 285 & 3.2 & 0.07 & 1 \\
\hline Separated & 44 & 84.62 & 8 & 15.38 & 52 & & & $2.79(.97-5.3)$ \\
\hline widowed & 24 & 72.73 & 9 & 27.27 & 33 & & & $1.35(.45-2.6)$ \\
\hline \multicolumn{9}{|l|}{ Income level } \\
\hline indebt & 58 & 90.63 & 6 & 9.38 & 64 & 16.5 & 0.0001 & $5.5(2.2-15)$ \\
\hline Just meet life expenses & 129 & 65.82 & 67 & 34.18 & 196 & & & $1.1(0.72-4)$ \\
\hline insufficient & 70 & 63.64 & 40 & 36.36 & 110 & & & 1 \\
\hline \multicolumn{9}{|l|}{ Parity } \\
\hline 0 & 27 & 62.79 & 16 & 37.21 & 43 & & & 1 \\
\hline 1 & 16 & 43.24 & 21 & 56.76 & 37 & 33 & 0.0001 & $0.45(0.29-2.6)$ \\
\hline 2 & 107 & 86.99 & 16 & 13.01 & 123 & & & $4(1.7-8.9)$ \\
\hline 3 & 92 & 63.89 & 52 & 36.11 & 144 & & & $1.05(.59-3.3)$ \\
\hline 4 & 15 & 65.22 & 8 & 34.78 & 23 & & & $1.1(0.29-3.7)$ \\
\hline
\end{tabular}

Table- 8 points out that there were statistically significant relations between the studied women's attitude about COVID-19 infection and their age, income level, and parity with $p$-value $<0.05$. Older women $\geq 30$ years had higher positive attitude about COVID-19 infection than younger women $(77.92 \%$ \&
$63.43 \%$ respectively). Moreover, women whose income level was indept and just meet life expenses had higher positive attitude about COVID-19 infection than those who had insufficient income $(90.63 \%, 65.82 \& 63.64 \%$ respectively). 


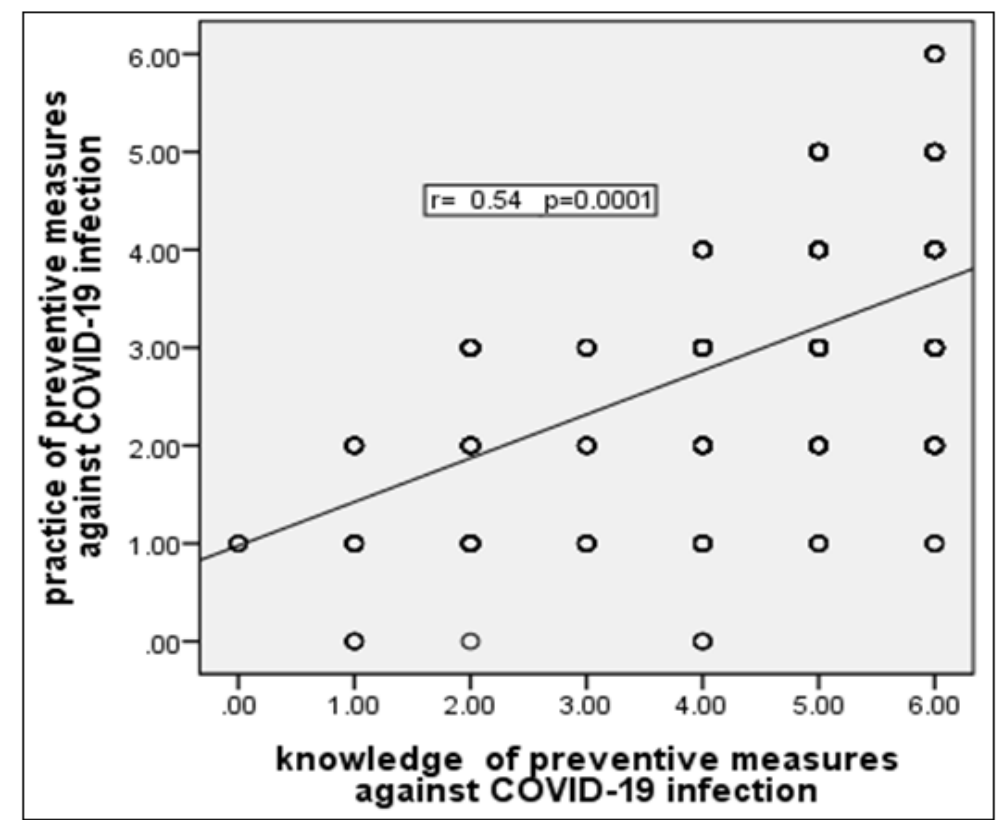

Fig-2: Correlation between knowledge and practice scores of preventive measures against COVID-19 infection among studied women

Figure-2 illustrates that, there was positive significant correlation $(\mathrm{r}=0.54 \& \mathrm{p}=0.0001)$ between knowledge and practice scores of preventive measures against COVID-19 infection among studied women.

\section{DISCUSSION}

According to RCOG [14], COVID-19 is an emerging infectious disease; the optimal treatment for affected individuals has not yet been established. It is important that vulnerable populations such as pregnant women be protected from coronavirus infection because pregnancy itself alters the body's immune system and response to viral infections in general, which can occasionally cause more severe symptoms and this will be the same for COVID-19.

This is particularly of great importance in Egypt countries because there is 287000 maternal deaths occur globally [15], with 1600 women dying owing to pregnancy and childbirth complications. Moreover, $80 \%$ of them can be preventable and treatable [16]. Therefore, poor practices of preventive measures against COVID-19 infection among pregnant women would put these women at high risk of infection which could worsen maternal morbidity and mortality profile during this coronavirus pandemic in Egypt.

The present study showed that the mean age of the studied women was $28.2 \pm 4.8$ years, ranged from 18 to 42 years. More than three fourth of them were married and housewives. More than half of them had secondary level of education, were living in rural areas and most of them were multiparous. This is congruent with Nwafor et al., [17] study in Nigeria about knowledge and practice of preventive measures against COVID-19 infection among pregnant women in a low- resource African setting who showed that the mean age of the study cohorts was $24.6 \pm 6.3$ years, ranged from 18 to 42 years. Majority of the participants were married, multiparous, farmers and reside in urban area. Most of the participants and their husbands had some formal education.

The current study illustrated that, the most common source of women's information on preventive measure against COVID-19 infection was television followed by internet, friends and relatives and health workers. The same results were observed by Nwafor et al., [17] who reported that the commonest source of information for the participants was the television, followed by friends and relatives, Health workers and internet.

These results were in disagreement with Abdelhafiz et al., [13] who conducted a study to assess the knowledge, perceptions and attitude of the Egyptian public towards the COVID-19 disease in Egypt who stated that, all participants claimed that they had heard about COVID-19. The most commonly stated sources of knowledge were social media.

The present study demonstrated that, all of the women were aware of ongoing COVID-19 infection. This is in agreement with Nwafor et al., [17] who reported that all the study participants were aware of the COVID-19 infection global pandemic and this results also matching with Zhong et al., 18] who assess knowledge, attitudes, and practices towards COVID-19 among Chinese in China who found that, most respondents had knowledgeable about COVID-19. This reflects the effectiveness of the message provided by the different media platforms, which was confirmed by the negative assumptions that the media is exaggerating 
the danger of the disease according to the information provided by the WHO and the Egyptian Ministry of Health $(\mathrm{MOH})$ to the public.

In our study, participants showed a positive general attitude towards measures that can be followed to prevent the transmission of the disease. They believed in the value of hand washing, covering mouth and nose when coughing or sneezing, avoid touching eyes, nose and mouth with hands, wear face mask, stay at home and limited personal contact. This in the same line with study of Zhong et al., [18] in China who reported that almost all participants in a Chinese study used to put face masks when they go out during the current pandemic. The development of vaccine is estimated to require months, and the management of this crisis depends primarily on people's adherence to the recommended measures taken.

The present study finding revealed that, the majority of women had unsatisfactory level of total practice of preventive measures of COVID-19 infection. This corresponds well with the study of Nwafor et al., [17] who reported that, most of the participants' practices to prevent coronavirus infection transmission were within poor practice category. This could be attributed to socio-demographic characteristics of the population in Egypt such as high parity, rural residence, low educational level and occupations requiring physical contacts were the factors associated with poor practice of preventive measures against the disease. These factors increase pregnant women's risk of exposure and contracting coronavirus disease as it continued to spread in Egypt.

In current study, the total knowledge score was significantly higher among younger women and those with higher income level. These results are similar to the results of Zhong et al., [18] study, in which participants with high socioeconomic status were knowledgeable, and followed appropriate practices to prevent the spread of COVID-19.

\section{CONCLUSION}

According to the findings of the present study, it can be concluded that most of the women had adequate knowledge of preventive measures against COVID-19 infection. However, the practice of these preventive measures was poor among them. Educational level and multiparity were factors significantly associated with poor practice of the preventive measures against coronavirus -19 infection among pregnant women. In addition, good COVID-19 knowledge is associated with optimistic attitudes and appropriate practices towards COVID-19.

\section{RECOMMENDATIONS}

- Pregnant women should be given instructional booklets in order to raise practice level of preventive measures of COVID-19 infection.
- All patients including pregnant women should be evaluated for fever and signs and symptoms of a respiratory infection. Ideally, screening procedures begin before arrival on a labor and delivery unit or prenatal care clinic.

- Health education programs to improve COVID-19 knowledge are helpful for encouraging an optimistic attitudes and maintaining safe practices.

- Further research studies are needed to assess the effect of COVID-19 on pregnant women.

\section{REFERENCES}

1. The Novel Coronavirus Pneumonia Emergency Response Epidemiology Team. (2020). The epidemiological characteristics of an outbreak of 2019 novel coronavirus diseases (COVID-19) in China. Chin Journal Epidemiol, 41:145-51.

2. Chen, N., Zhou, M., Dong, X., Qu, J., Gong, F., Han, Y., ... \& Yu, T. (2020). Epidemiological and clinical characteristics of 99 cases of 2019 novel coronavirus pneumonia in Wuhan, China: a descriptive study. The Lancet, 395(10223), 507 513.

3. Rasmussen, S. A., Smulian, J. C., Lednicky, J. A., Wen, T. S., \& Jamieson, D. J. (2020). Coronavirus Disease 2019 (COVID-19) and Pregnancy: What obstetricians need to know. American journal of obstetrics and gynecology.

4. World Health Organization. (2020). Coronavirus (COVID-19). https://who.sprinklr.com. Accessed May 7, 2020.

5. Egyptian ministry of health. (2020). COVID-19 outbreak daily report in Egypt situationreport [NCDCwebsite]. 2020. https://ncdc.gov.ng/diseases/sitreps/?cat=14\&nam $\mathrm{e}=\mathrm{An} \% 20$ update $\% 20$ of $\% 20$ COVID19\%20outbreak\%20in\%20Nigeria.AccessedApril1 5,2020 .

6. Zhou, F., Yu, T., Du, R., Fan, G., Liu, Y., Liu, Z., ... \& Guan, L. (2020). Clinical course and risk factors for mortality of adult inpatients with COVID-19 in Wuhan, China: a retrospective cohort study. The lancet.

7. Royal college of obstetricians and gynecologists. (2020). Coronavirus (COVID-19) infection in pregnancy information for healthcare professionals. RCOG, London.

8. Qiao, J. (2020): What are the risks of COVID-19 infection in pregnant women?. The Lancet; 395(10226):760-762.

9. Chen, D., Yang, H., Cao, Y., Cheng, W., Duan, T., Fan, C., ... \& He, J. (2020). Expert consensus for managing pregnant women and neonates born to mothers with suspected or confirmed novel coronavirus (COVID- 19) infection. International Journal of Gynecology \& Obstetrics, 149(2), 130136.

10. Poon, L. C., Yang, H., Kapur, A., Melamed, N., Dao, B., Divakar, H., ... \& Di Renzo, G. C. (2020). Global interim guidance on coronavirus disease 
2019 (COVID- 19) during pregnancy and puerperium from FIGO and allied partners: Information for healthcare professionals. International Journal of Gynecology \& Obstetrics, 149(3), 273-286.

11. Nie, R., Wang, S. S., Yang, Q., Fan, C. F., Liu, Y. L., He, W. C., ... \& Oktay, K. (2020). Clinical features and the maternal and neonatal outcomes of pregnant women with coronavirus disease 2019. medRxiv.

12. World Health Organization. (2020): Coronavirus disease (COVID-19) advice for the public [WHO b:website].

https://www.who.int/emergencies/diseases/novelcoronavirus-2019/advice-for-public. Accessed April 25, 2020.

13. Abdelhafiz, A. S., Mohammed, Z., Ibrahim, M. E., Ziady, H. H., Alorabi, M., Ayyad, M., \& Sultan, E. A. (2020). Knowledge, Perceptions, and Attitude of Egyptians Towards the Novel Coronavirus Disease (COVID-19). Journal of Community Health, 1-10.

14. Royal college of obstetricians and gynecologists (RCOG). (2020). Coronavirus (COVID-19) infection in pregnancy information for healthcare professionals. RCOG, London.

15. WHO, UNICEF, UNFPA and The World Bank. (2012). Trends in maternal mortality: 1990-2010. Geneva, Switzerland: World Health Organization. Back to cited text no. 27.

16. WHO, UNICEF, UNFPA, The World Bank, and the United Nations Population Division. (2014). Trends in maternal mortality: 1990-2013. Geneva, Switzerland: World Health Organization. Back to cited text no. 28.

17. Nwafor, J. I., Aniukwu, J. K., Anozie, B. O., \& Ikeotuonye, A. C. (2020). Knowledge and practice of preventive measures against COVID-19 infection among pregnant women in a lowresource African setting. medRxiv.

18. Zhong, B. L., Luo, W., Li, H. M., Zhang, Q. Q., Liu, X. G., Li, W. T., \& Li, Y. (2020). Knowledge, attitudes, and practices towards COVID-19 among Chinese residents during the rapid rise period of the COVID-19 outbreak: a quick online crosssectional survey. International journal of biological sciences, 16(10), 1745-1752. 